
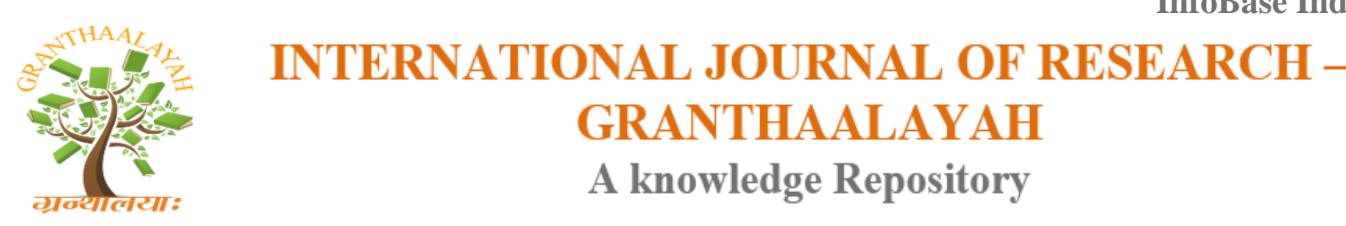

\title{
Social
}

\section{UTILIZATION OF INSTRUCTIONAL MEDIA IN TEACHING SCIENCE}

\author{
S. Jamuna ${ }^{* 1}$, Mrs. Pankajam. $\mathbf{R}^{2}$ \\ ${ }^{* 1}$ MSc., M.Phil., MEd Scholar, RVS College of Education, India \\ ${ }^{2}$ M.Sc., M.Sc (Psy), M.Phil, M.Ed., M.Phil, (Edu), Assistant Professor in Physical Science, RVS \\ College of Education, India \\ DOI: https://doi.org/10.29121/granthaalayah.v5.i3(SE).2017.1940
}

\begin{abstract}
There is no doubt that instructional media has gained wider acceptability and usability. Instructional media has the potentials of influencing decision-making in a very short time regardless of the distance. The aim of the study was to analyze the utilization of social media among school teachers in Tirupur District. School teachers working in Tirupur District constitute the population of the study. From the population 150 schools Teachers working in Tirupur district were randomly selected as sample. A Questionnaire on the utilization of instructional media in teaching science developed by Babyrani.A (2010) has been adopted as research tool to collect the data. Findings of the study reveal that majority of science teachers was found on moderate level in utilization of instructional media in teaching science. Gender has no influence but locality has strong influence in utilization of instructional media in teaching science.
\end{abstract}

Keywords: Instructional Media; Teaching Science; Education.

Cite This Article: K. Jamuna, and Mrs. Pankajam. R. (2017). "UTILIZATION OF INSTRUCTIONAL MEDIA IN TEACHING SCIENCE." International Journal of Research - Granthaalayah, 5(3)SE, 51-56. https://doi.org/10.29121/granthaalayah.v5.i3(SE).2017.1940.

\section{Introduction}

The term "instructional media", according to Romiszowski (1988), refers to devices and materials employed in teaching and learning. It includes hardware like blackboards, radio, television, tape recorders, video tapes and recorders and projectors; and, software like transparencies, films, slides, teacher-made diagrams, real objects, cartoons, models, maps and photographs (Opoku-Asare, 2004:36). Similarly, Scanlan (2003) indicates that instructional media encompasses all the materials and physical means an instructor might use to implement instruction and facilitate students' achievement of instructional objectives. This may include traditional materials such as chalkboards, handouts, charts, slides, overheads, real objects, and videotape or film, as well newer materials and methods such as computers, DVDs, CD-ROMs, the Internet, and interactive video conferencing. 
Talabi (2001) asserts that instructional media are generally designed to provide realistic images and substitute experience to reach curriculum experiences. The media are considered the most efficient facilitators in the education set up. They are not substitutes for the teacher. Their use however, calls for an imaginative approach by the teacher who needs to constantly be on the alert for new ideas and techniques to make the lessons presented with different instructional media achieve effective outcomes.

According to this author, some devices are designed to present information of a kind that would not be available in an ordinary school experience. Examples include, films, television, sound recordings. Other types of instructional media have the function to help the pupil grasp the underlying structure of a phenomenon. Visual media are primarily for seeing, audio devices for hearing, and multi-sensory materials for use via two or more senses.

Nkuuhe (1995) holds the view that instructional media are all devices and materials used in the teaching and learning process. According to Nyame-Kwarteng (2006), instructional media are the various materials that appeal to the five senses- seeing, hearing, touching, feeling and tasting which enhance teaching and learning.

Ogunmilade (1984) also identifies instructional media as devices of hardware (equipment) and software (consumables) through which the learning process may be ensured and carried out.

In other words, they are the collection of materials and equipment that can be used effectively for communication. These materials are used in the planning process of giving instruction. Instructional media with its various types affect different senses and act as an integral part of teaching and learning process, and thus helping to bring about meaningful experiences. In this study, instructional media refers to models, real objects and other materials in addition to the chalkboard and textbooks that are brought to the teaching and learning process to induce understanding.

The place of instructional media in the teaching and learning process is undoubtedly essential. Scanlan assert that instructional media are used whenever, in the best judgment of the teacher, it can facilitate learning or increase understanding of material being presented.

It must be said that different instructional media exist to meet the different capabilities of learners. Whether for the purposes of seeing or hearing and others for seeing and hearing at the same time, instructional media are intended to bring about meaningful understanding and hence learning. There are certain advantages and disadvantages that have to be considered to ensure their proper selection and use.

\section{Research Questions}

- Is there any difference in the level of utilization of instructional media in teaching science among school teachers?

- Is there any difference in utilization of instructional media in teaching science between the groups based on sex among the school teachers? 
- Is there any difference in the utilization of instructional media in teaching science between urban and rural school teachers?

\section{Hypothesis}

- There will be a difference in the level of utilization of instructional media in teaching science among school teachers.

- There will be a significant mean score difference in utilization of instructional media between the groups based on sex among the school teachers.

- There will be a significant mean score difference in the utilization of instructional media in teaching science between urban and rural school teachers.

\section{Population and Sample}

School teachers working in Tirupur District constitute the population of the study. From the population 150 schools Teachers working in Tirupur district were randomly selected as sample.

\section{Tool Used}

In the present study a tool on the utilization of instructional media in teaching science has been adopted which is in the form of questionnaire developed by Babyrani.A (2010) to collect the data for research. It is a three point scale. For positive statements 3,2 and 1 were the scores given to the responses always, sometimes and never respectively. For negative statements it reversed.

\section{Data Collection}

The data was collected using a questionnaire which was modified after the analysis of the pilot study. The study is based on primary data which was collected from a sample of 150 science school teachers in government and private school in Tirupur district. Prior to the collection of data, the investigator got the permission from the school authorities.

The data was collected from the selected samples by using questionnaire. Totally the data was collected in 20 days. After the data collection, the investigator has employed the SPSS for analysis.

\section{Hypothesis 1:}

There will be a significant difference in the level of utilization of instructional media in teaching science among school teachers

Table 1: Frequency and percentage difference in the level of utilization of instructional media in teaching science among school teachers

\begin{tabular}{|c|c|c|c|c|c|c|c|c|}
\hline \multicolumn{3}{|c|}{ Low } & \multicolumn{4}{c|}{ Moderate } & \multicolumn{3}{c|}{ High } \\
\hline Q1 & F & \% & Q2 & F & \% & Q3 & F & \% \\
\hline 67 & 39 & $26 \%$ & 72 & 57 & $38 \%$ & 74 & 54 & $36 \%$ \\
\hline
\end{tabular}

Table 1 exhibits the result of the Utilization of instructional media in teaching science among school teachers. According to the table totally $26.6 \%$ of the selected school teacher belong to low level of Utilization of instructional media in teaching science, $38 \%$ of the selected school 
teachers belong to moderate level of Utilization of instructional media in teaching science and $36 \%$ of the selected school teachers belong to high level of Utilization of instructional media in teaching science. So the hypothesis No: 1 is accepted. Thus it is inferred that there is a difference in the level of utilization of instructional media in teaching science among school teachers.

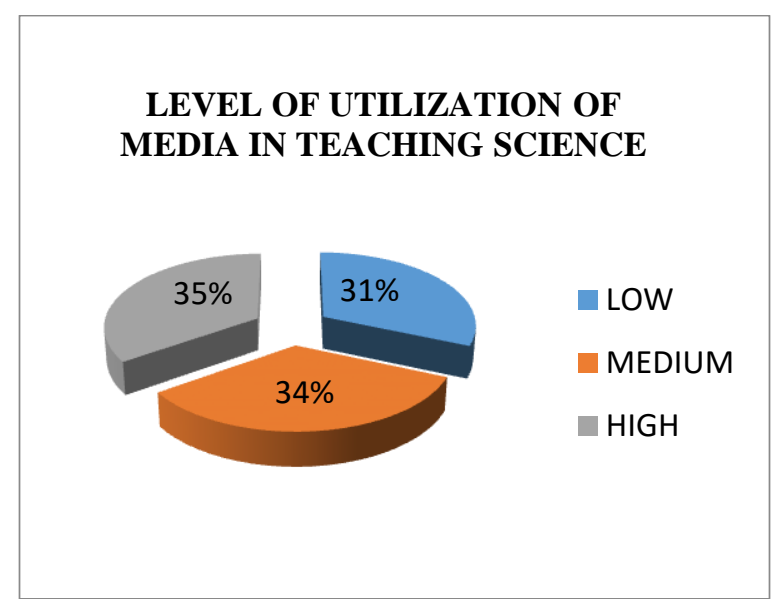

Chart 1: shows that difference in the level of utilization of instructional media in teaching science

\section{Hypothesis 2:}

There will be a significant mean score difference in utilization of instructional media in teaching science between the groups based on sex among the selected school teachers

Table 2: Means score difference and t-test of Utilization of instructional media between the groups based on sex among the selected school teachers

\begin{tabular}{|l|l|c|c|c|c|c|l|}
\hline \multicolumn{1}{|c|}{ Subject } & \multicolumn{1}{|c|}{ N } & Mean & \multicolumn{1}{|c|}{ S.D } & df & t-value & $\begin{array}{c}\text { p- } \\
\text { value }\end{array}$ & Result \\
\cline { 1 - 5 } Male & 26 & 6.9615 & 7.133453 & 150 & .602 & .586 & N.S \\
\hline Female & 124 & 7.0435 & 6.133000 & &
\end{tabular}

The Table 2 shows that mean score difference in Utilization of instructional media in teaching science between the groups based on sex among the selected school teachers. However totally, the calculated t-value is statistically not significant at 0.05 levels and hence, the hypothesis 2 is rejected. It can be concluded that there is no significant difference in Utilization of instructional media between the groups based on sex among the selected school teachers. 


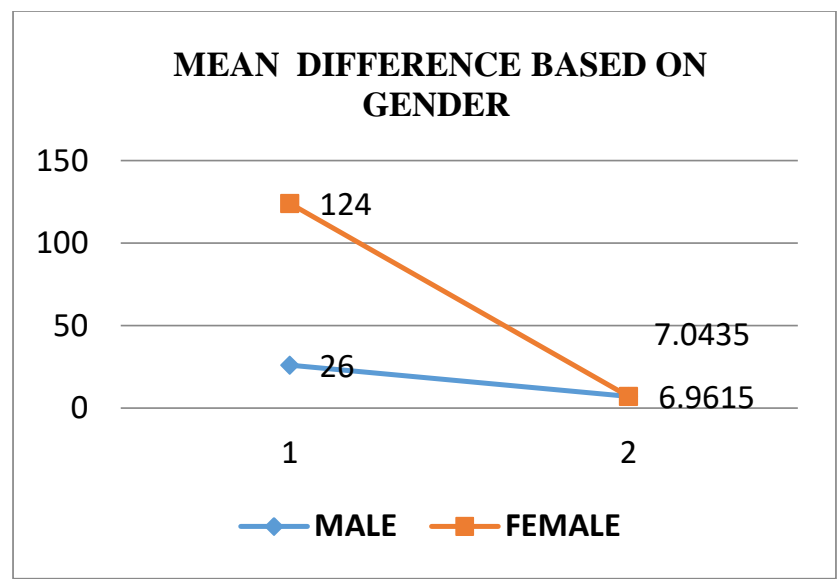

Chart 2: shows that mean difference in utilization of instructional media in teaching science

\section{Hypothesis 3:}

based on gender

There will be a significant mean score difference in the utilization of instructional media in teaching science between urban and rural school teachers.

Table 3: Means score difference and t-test of Utilization of instructional media in teaching science between urban and rural school teachers

\begin{tabular}{|l|c|c|c|c|c|c|l|}
\hline \multicolumn{1}{|c|}{ Subject } & \multicolumn{1}{|c|}{ N } & Mean & S.D & df & $\begin{array}{c}\text { t- } \\
\text { value }\end{array}$ & $\begin{array}{c}\text { p- } \\
\text { value }\end{array}$ & Result \\
\hline Rural & 38 & 7.1894 & 4.373072 & \multirow{2}{*}{150} & 1.828 & .006 & $\mathrm{~S}$ \\
\hline Urban & 112 & 6.9750 & 6.761710 & & & & \\
\hline
\end{tabular}

The Table 3 shows that mean score difference in Utilization of instructional media in teaching science between urban and rural school teachers. However totally, the calculated t-value is statistically significant at 0.05 levels and hence, the hypothesis 3 is accepted. It can be concluded that there is a significant difference in Utilization of instructional media in teaching science between urban and rural school teachers.

So, teachers in the rural area use less instructional media in teaching science.

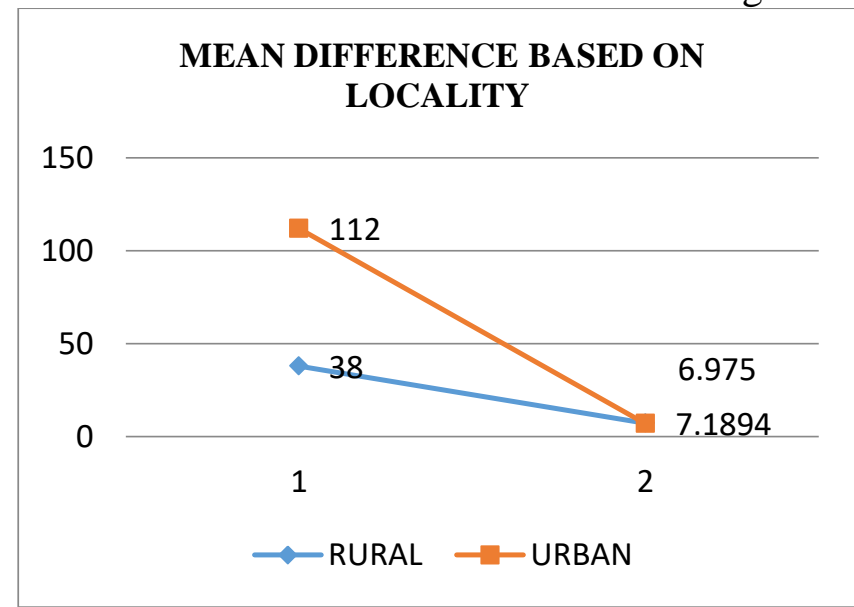

Chart 3: shows that mean difference in utilization of instructional media in teaching science based on locality 


\section{Findings}

There is a difference in the level of utilization of instructional media in teaching science among school teachers. It is found that $26.6 \%$ of the selected school teachers belong to low level of Utilization of instructional media in teaching science, $38 \%$ of the selected school teachers belong to moderate level of Utilization of instructional media in teaching science, $36 \%$ of the selected school teachers belong to high level of Utilization of instructional media in teaching science. There is no significant mean score difference in utilization of instructional media between the groups based on sex among the school teachers. There is a significant mean score difference in the utilization of instructional media in teaching science between urban and rural school teachers. Teachers in the rural area use less instructional media in teaching science.

\section{Conclusion}

A study on utilization of instructional media in teaching science among school teachers was studied and the findings reveal that the difference of large majority of science teachers was found moderate level of difference in utilization of instructional media in teaching science. Gender has no influence but locality has strong influence in utilization of instructional media in teaching science. So based on these results the teachers shall be encouraged to use instructional media in teaching and learning process for the betterment of the academic performance of the students in the present scenario.

\section{References}

[1] Arreguin, C. (2004). Wikis. In B. Hoffman (Ed.), Encyclopedia of Educational Technology.Retrieved on 22nd may 2011 from http://coe.sdsu.edu/eet/Articles/wikis/start.htm.

[2] Constructivist Learning Theory. Retrieved from the World Wide Web November 2, 2002from http://www.artsined.com/teachingarts/Pedag/Dewey.html

[3] David, S. (2014). Advantages and disadvantages of facebook. Journal of Business Education, $1(2), 155-162$

[4] Golden, S. A. R. (2016). RURAL STUDENTS'ATTITUDE TOWARDS ENGLISH AS MEDIUM OF INSTRUCTION IN HIGHER EDUCATION-AN ANALYSIS. International Journal of Research, 3, 1-10.

[5] Golden, S. A. R. (2017). Attitude of Students and Teachers towards E- Learning - An Analysis. Recent Research in Social Science \& Humanities, 1, 5-10.

[6] Gupta, D.S. (2014). Social media for teachers of English: A hub for professional development. Research Journal of English language and literature 2(2), 34-38

[7] Ibrahim, L. (2012). Social media and its influence on students' performance. Jamb News, 3(21), 4-5.

[8] Kirschner, P.A. and Karpinski,A.C.(2010). Facebook and academic Performance. computers in human behavior, 26(6), 1237-124

[9] Obi N. C., Bulus L. D. Adamu G. M. \&Sala'at A. B. (2012). The need for safety consciousness among youths on social networking sites. Journal of Applied Science and Management (JASM) 14(1), 40-45 